\section{A practical guide to the management of anophthalmia and microphthalmia}

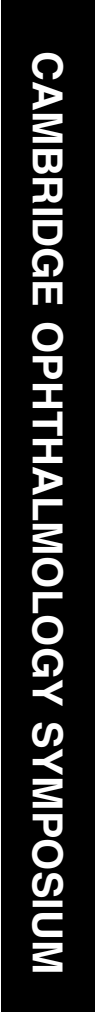

Department of

Ophthalmology, Moorfields

Eye Hospital, London, UK

Correspondence: NK Ragge, Department of

Ophthalmology,

Moorfields Eye Hospital,

City Road,

London EC1 2PD, UK

Tel: + 02075662577 ;

Fax: + 02075662972

E-mail: nicky.ragge@

dpag.ox.ac.uk

Received: 7 March 2007

Accepted: 4 April 2007

\begin{abstract}
Congenital anophthalmia and microphthalmia are rare developmental defects of the globe. They often arise in conjunction with other ocular defects such as coloboma and orbital cyst. They may also be part of more generalised syndromes, such as CHARGE syndrome. Anophthalmia, microphthalmia, and coloboma are likely to be caused by disturbances of the morphogenetic pathway that controls eye development, either as a result of primary genetic defect, or external gestational factors, including infection or drugs that can influence the smooth processes of morphogenesis.
\end{abstract}

The ophthalmologist is often the primary carer for children with anophthalmia and microphthalmia, and as such can coordinate the multidisciplinary input needed to offer optimal care for these individuals, including vision and family support services. They are able to assess the vision and maximise the visual potential of the child and they can also ensure that the cosmetic and social impact of anophthalmia or microphthalmia is minimised by starting socket expansion or referring to a specialist oculoplastics and prosthetics unit. A coordinated approach with paediatrics is necessary to manage any associated conditions. Genetic diagnosis and investigations can greatly assist in providing a diagnosis and informed genetic counselling. Eye (2007) 21, 1290-1300; doi:10.1038/sj.eye.6702858

Keywords: anophthalmia; microphthalmia; coloboma; cyst; prosthesis; hydrophilic expander

\section{Background}

Congenital anophthalmia and microphthalmia are rare defects of the globe resulting from abnormalities in the development of the primary optic vesicle. Anophthalmia has an incidence of $0.18-0.4 / 10000$ births $^{1,2}$ and microphthalmia around 1.5-19/10 000 births., ${ }^{2,3}$ The term anophthalmia is used where there is no visible ocular remnant. However, ultrasound often reveals a buried microphthalmic remnant or cyst. Microphthalmia refers to an eye with reduced volume and may be associated with coloboma or with an orbital cyst. It may usefully be subdivided into microanterior segment (when the overall axial length may be normal or even increased), and microposterior segment, since each of these may have a different underlying aetiology. There is a spectrum of disease that exists between these conditions. Both anophthalmia and microphthalmia may be unilateral or bilateral, and over $50 \%$ may be associated with systemic abnormalities ${ }^{4}$ (and Ragge, unpublished data). In the case of unilateral anophthalmia or microphthalmia, there may be developmental anomalies of the other eye, including coloboma, lens, and optic nerve abnormalities. ${ }^{5,6}$

\section{Assessment in the neonatal unit}

The management of a child presenting with suspected anophthalmia or microphthalmia benefits from the coordinated involvement of a multidisciplinary team of health care professionals. The initial assessment is likely to be carried out by a paediatrician and/or paediatric ophthalmologist in the neonatal period. Early examination by an ophthalmologist is crucial and will include both a diagnostic and visual assessment, leading to an early management plan. The initial meeting with the parents allows the ophthalmologist to explain both the condition and the likely management plan. The parents are likely to be deeply traumatised early on, especially if the findings were not predicted prenatally, and a 
discussion of diagnosis, if known, and likely aetiology and investigations is helpful at this stage.

An early paediatric assessment involves a full examination of the whole child to search for any associated systemic abnormalities. The child may already be known to have significant other medical problems, requiring active management even at this stage. Particular attention is focused upon the face, including ear and palate, the cardiac system, genital anomalies, feeding difficulties, which might indicate oesophageal abnormality, and metabolic disturbances, which may indicate pituitary underaction. A management or referral plan is then made depending on any systemic abnormalities identified.

\section{Assessment in the eye clinic}

As soon as possible in the first few weeks after birth, the child will be assessed in the paediatric eye clinic. If there are severe ocular anomalies, the assessment would be best carried out in the first 2 weeks of life. The history will focus on trying to make a diagnosis by establishing any other ocular or systemic features, and identifying aetiological factors, in particular any relevant gestational factors or family history of other ocular or systemic abnormalities. The diagnostic assessment confirms anophthalmia, microphthalmia, coloboma, orbital cyst, or other associated ocular pathology. It is important to examine both eyes since in cases of unilateral anophthalmia or microphthalmia the fellow eye may show other, more subtle, abnormalities such as coloboma, optic nerve hypoplasia, retinal dystrophy, or cataract. An ultrasound of the eye and orbit can be useful to determine the internal structure of the eye, the presence of an ocular remnant or cyst, where this is not immediately visible, and to determine axial length in cases of microphthalmia.

Vision is assessed using early paediatric vision tests, and electrodiagnostics if necessary. A flash visual evoked potential (VEP) will establish if any vision is present in cases of apparent anophthalmia or severe

microphthalmia; a pattern VEP will both establish a level of acuity and detect any optic nerve dysfunction, and an electroretinogram will identify if there is retinal dysfunction.

Children with even quite severe microphthalmia may have some vision and it is important to establish this early on, especially in bilateral cases, as it will guide the approach to socket expansion (Figure 4).

\section{Investigations and screening}

The child will need several investigations in addition to orbital ultrasound and electrodiagnostic testing. Since many conditions that affect ocular development also affect brain development, it is important to arrange imaging of the brain, particularly looking at midline structures, the hippocampus and periventricular structures. Magnetic resonance imaging (MRI) is preferable to computed tomography scanning since there is higher resolution of the structures of interest and no radiation exposure (important in conditions such as Gorlin syndrome). Renal ultrasonography is also recommended given the association between eye and renal anomalies. The paediatrician is also likely to have screened for intrauterine infections. Congenital rubella has long been associated with microphthalmia ${ }^{7}$ and it would be important to exclude this given an appropriate history during pregnancy. There have also been case reports of microphthalmia associated with other intrauterine infections such as varicella, Toxoplasma gondii, herpes simplex virus, and cytomegalovirus. ${ }^{8-11}$ In addition, early assessment of hearing is particularly important to allow prompt intervention in the case of abnormality.

Examination of other family members for related ocular pathology such as anophthalmia or microphthalmia, anterior segment malformation, glaucoma, coloboma, retinal dystrophy, and optic nerve hypoplasia is important since this may provide a clue to likely diagnosis or inheritance pattern. Genetics assessment will include chromosome analysis and testing of particular genes. In our centre, we routinely carry out fine resolution chromosome analysis and screening of a wide range of genes on a research basis or in collaboration with various diagnostic laboratories.

\section{Management}

The management of children with anophthalmia or microphthalmia is often best achieved through a shared care approach between the local ophthalmic and paediatric services and a specialist centre. To maximise the visual potential of the child glasses are prescribed for any significant refractive error and, in the case of children with only one, sighted eye for protection.

\section{Socket expansion}

Early socket expansion is important to minimise facial deformity and can be started very soon after birth in cases of anophthalmia or severe microphthalmia. This is best carried out in a specialist unit with a good ocular prosthetic service available. The normal eye in a child at birth is approximately $70 \%$ of its adult size. By contrast, the face even by 3 months is only $40 \%$ of adult face size. There is, however, rapid growth of the face and by 2 years it is $70 \%$ of adult size and by 5.5 years $90 \%$ of 
adult size. ${ }^{12}$ Normal facial and orbital development is affected by reduction in ocular volume and in cases of anophthalmia and moderate or severe microphthalmia there is often underdevelopment of the bony orbit, the eyelids, and the fornices. Without intervention, the socket remains underdeveloped and the ability to wear a prosthesis in later life is compromised. In unilateral cases the asymmetry becomes more pronounced as the child grows. The cosmetic deformity that can ensue without intervention can lead to marked difficulties with social interaction. With appropriate treatment the cosmetic outcome is greatly improved (Figures 1-7).

Progressive growth of the socket can be facilitated by adding volume to the socket using socket expanders. Traditionally, this involved frequent visits to hospital for sequential socket expansion using progressively larger acrylic shapes with or without moulding of the socket under anaesthesia. However, more recently the use of hydrophilic expanders has allowed a relatively non-invasive start to the expansion process and a reduction in the number of initial visits to hospital needed to produce satisfactory socket expansion. ${ }^{13,14}$ Hydrophilic expanders, for example those manufactured by $A c r i . \mathrm{Tec}^{\circ}$, are available in several sizes and are placed, or sutured, in the socket, along with topical preservative-free antibiotic drops. The lids are then closed over the expander with a temporary tarsorrhaphy, secured either by suturing or with histoacryl glue. In our experience, glue is easier, can be performed in clinic under topical anaesthetic and leads to very few complications. A painted prosthesis is then introduced as appropriate (Figure 5). This is usually increased in size at regular intervals until symmetry is achieved or no more expansion is possible. In some cases, additional reconstruction, such as a primary orbital implant in anophthalmic, or severely microphthalmic, non-seeing eyes, may be necessary. This allows use of a smaller painted prosthesis, which is easier to insert and remove. The parents and eventually the child are taught how to manage the prosthesis, although frequent checks by an ocularist will continue to be needed.

In the case of microphthalmic eyes, especially where there is vision, the situation is a little different and management varies according to the centre. Where the microphthalmic eye has an axial length of less than $16 \mathrm{~mm}$ (Collin, unpublished observation), it is unlikely to promote normal orbital growth alone and it is therefore necessary to increase the socket volume early on to prevent asymmetry becoming more pronounced as the child grows. In this situation, a purpose-made cosmetic shell can be fitted over the microphthalmic eye or ocular remnant to promote orbital growth. Clear shapes will need to be fitted initially in the case of eyes with a positive VEP, or with a good-sized eye with a cornea. In bilateral cases, this will need to continue throughout life (Figure 6). Since hydrophilic expanders are translucent, they can be fitted in front of severely microphthalmic eyes with light perception without the fear of blocking out the vision. However, they cannot be used with moderately microphthalmic eyes since these need clear moulded shapes in front of them to avoid damage to the underlying eye (Figure 1).

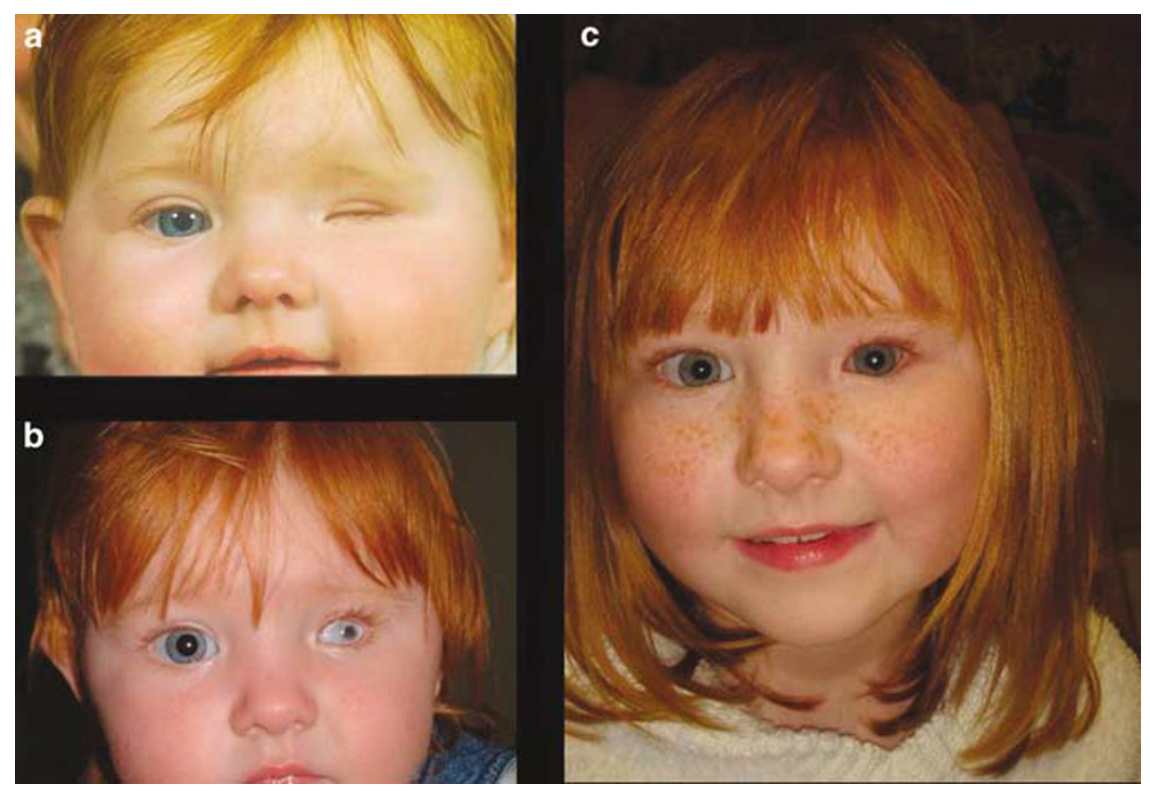

Figure 1 Girl with left microphthalmia (a) before socket expansion with cosmetic shell (b) view of microphthalmic eye (c) appearance wearing cosmetic shell over L microphthalmic eye. 

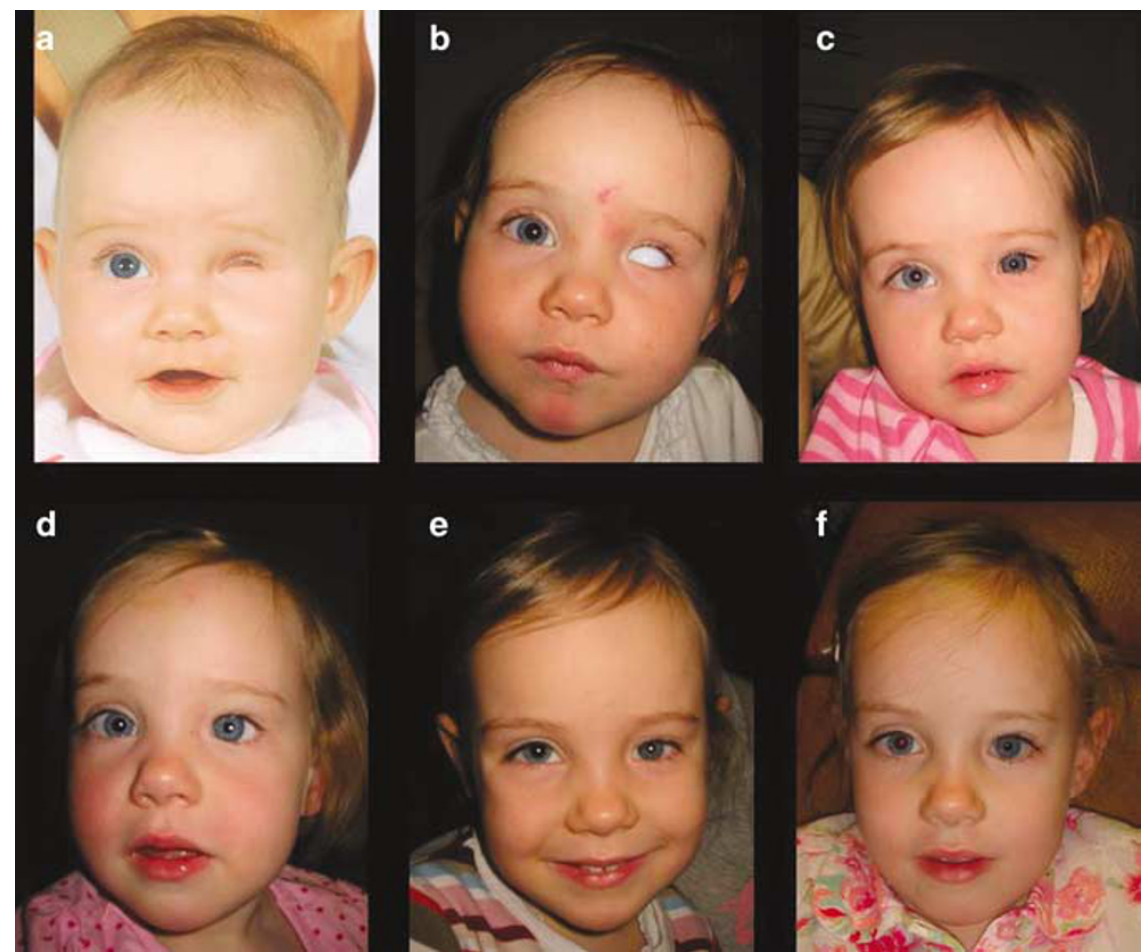

Figure 2 Girl with $\mathrm{L}$ anophthalmia undergoing sequential socket expansion using solid shapes. Note initial slanting of $\mathrm{L}$ brow, which signifies a smaller L orbit, and subsequent symmetry of brows. (a) 5 months old, (b) 15 months old, (c) 21 months old, (d) 2 years 2 months old, (e) 3 years 10 months, (f) 5 years 3 months.

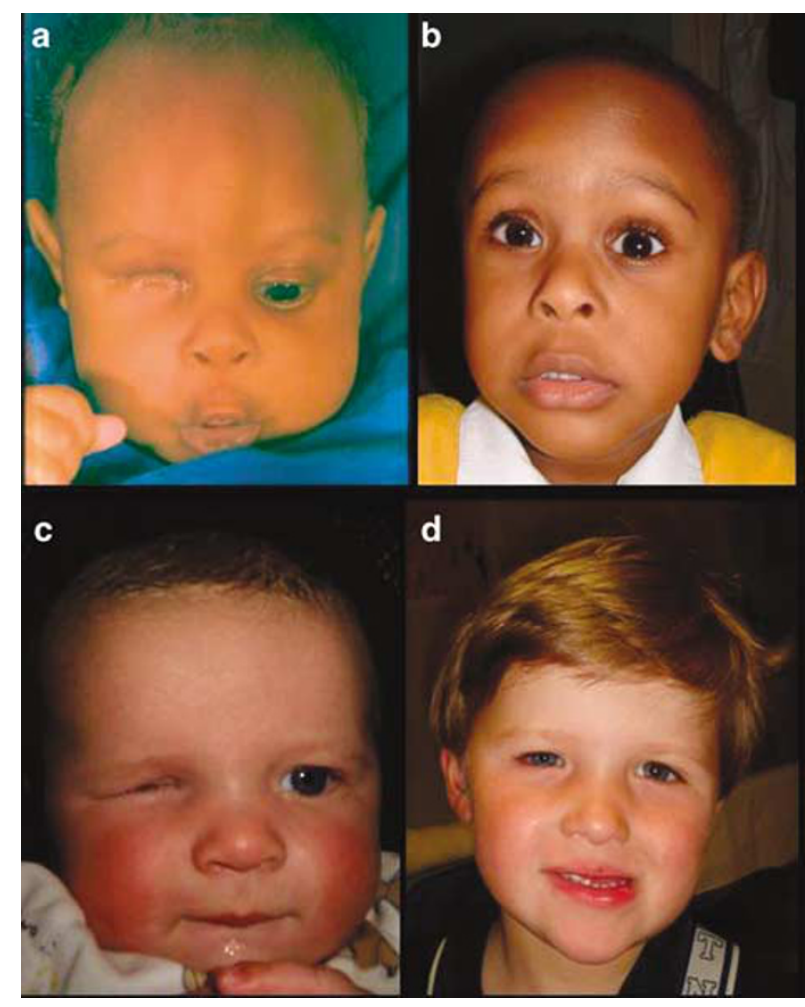

Figure 3 Two boys with R anophthalmia (a and c) as young babies before socket expansion using solid shapes and ( $b$ and $d$ ) demonstrating symmetrical socket appearance.

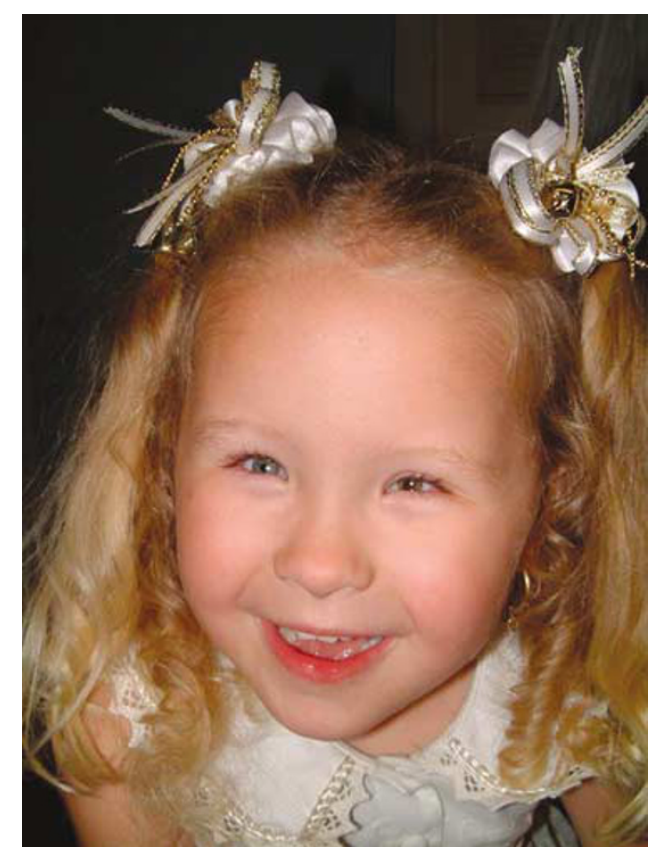

Figure 4 Girl with $\mathrm{R}$ extreme microphthalmia and left microphthalmia and coloboma wearing a right prosthesis to match the microphthalmic left eye.

Some centres will remove a non-seeing eye, and use a dermis fat graft/ball implant at an early stage. Our preference, however, is to preserve the microphthalmic 
eye even if there is no visual potential. The advantages of this approach are that the microphthalmic eye is likely to provide some stimulus to palpebral aperture and socket growth, especially where the microphthalmia is only mild or where there is an associated orbital cyst and it avoids the need for early invasive surgery with all its accompanying risks. ${ }^{15}$ A clear conformer is created and inserted, allowing the health of the underlying microphthalmic eye to be observed. Subsequently, when the fit is satisfactory, a hand-painted prosthesis can be made. In mild or moderate microphthalmia, this needs good clearance over the cornea. In severe unilateral microphthalmia, it will fill the available socket space.

When the axial length of the eye is over $16 \mathrm{~mm}$, or if there is a large cyst present, the fitting of such a prosthesis is more optional, as orbital growth is more likely to be normal (although this should be kept under observation). The timing is then governed by social and aesthetic need, for example a good time to introduce a prosthesis might be just before the child starts school.

The question of when to change a clear prosthesis over a unilateral microphthalmic eye with some vision

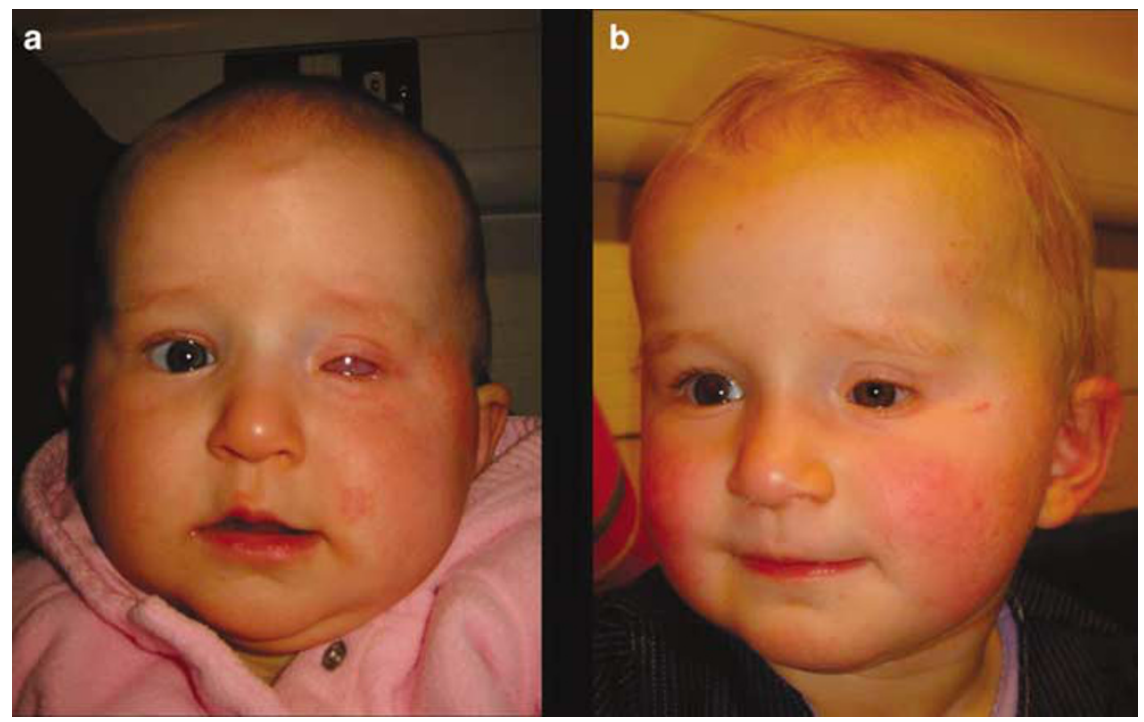

Figure 5 The results of socket expansion using hydrophilic expanders are seen in this girl with L anophthalmia (a) with hydrophilic expander in situ and (b) with first painted prosthesis.

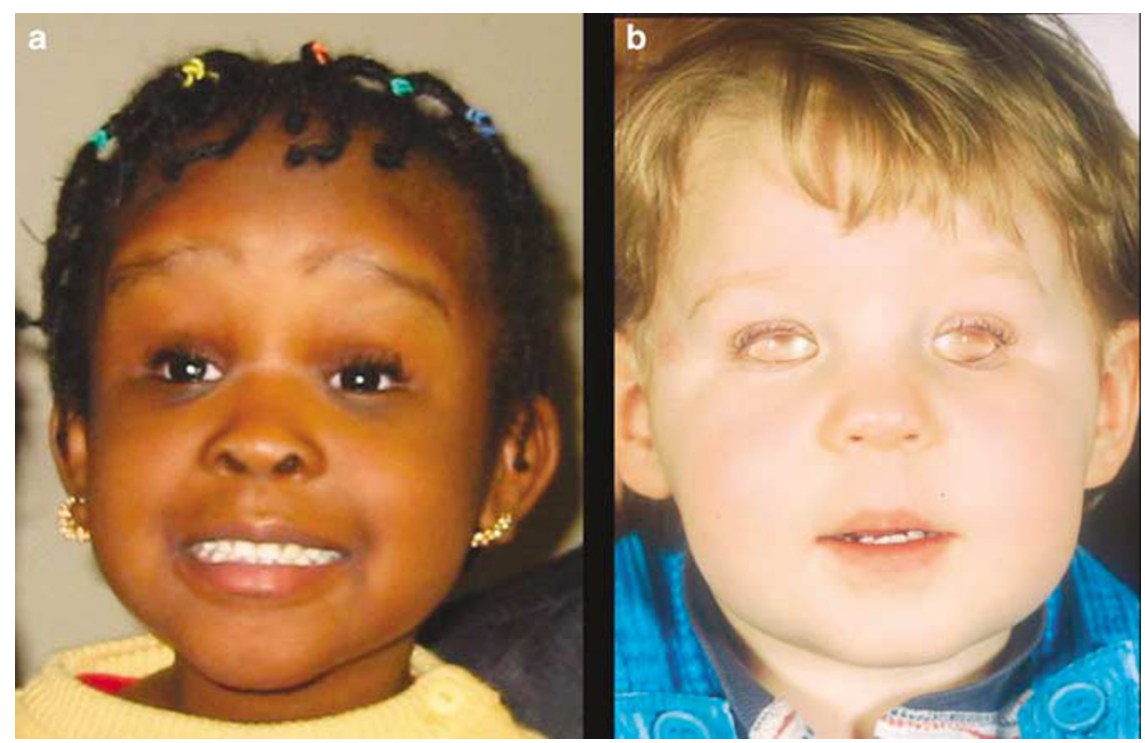

Figure 6 (a) Girl with bilateral severe microphthalmia and no perception of light wearing bilateral prostheses. (b) Boy with clinical anophthalmia, but with light perception wearing clear prostheses. 


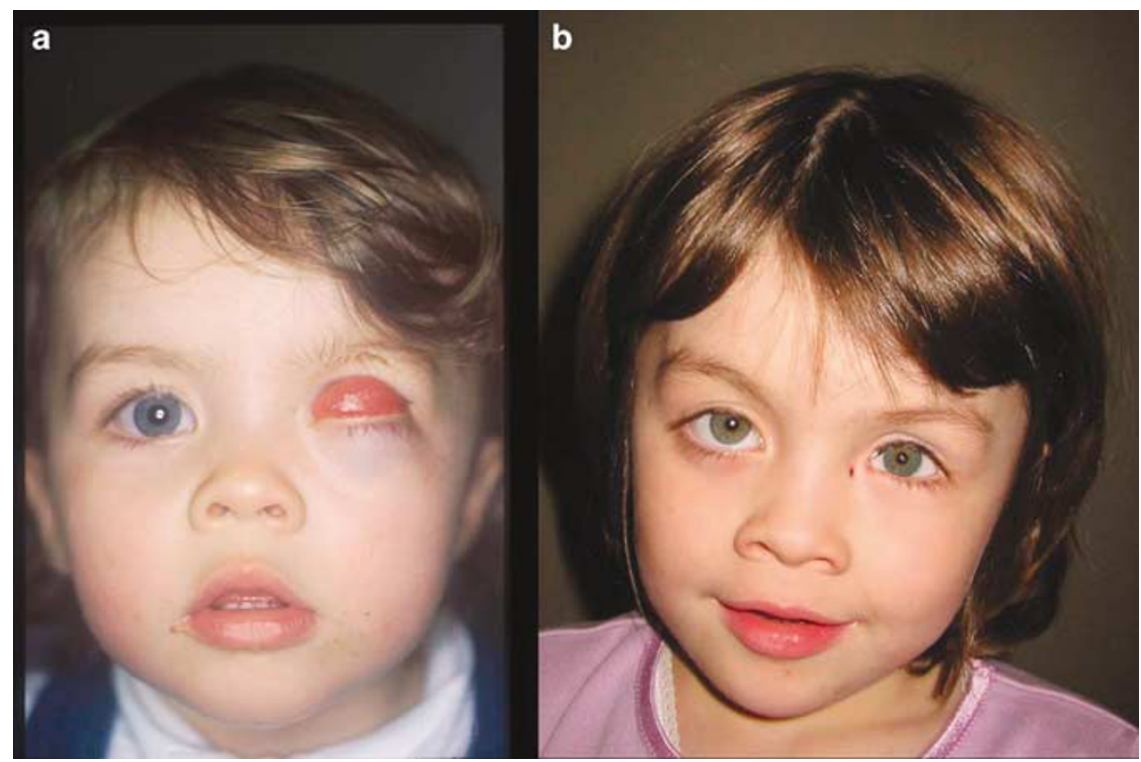

Figure 7 Girl with L microphthalmia and cyst (a) cyst in situ acting as socket expander, (b) post-removal preserving the microphthalmic eye and wearing L painted prosthesis.

(such as light perception) for a painted prosthesis is difficult. A clear prosthesis allows the maximum visual potential of the microphthalmic eye to be reached and the health of the underlying eye to be checked. However, once a stable situation is reached, the vision is unlikely to be lost even if the microphthalmic eye is covered, and better cosmesis, and probably better vision and stability of the good eye will be achieved if a painted prosthesis is fitted (Figure 1). ${ }^{16}$

For patients with anophthalmia or microphthalmia and a large orbital cyst, gradual socket enlargement can usually be achieved using the natural expansion produced by the cyst (Figure 7). The parents may need gentle reassurance that this is the best policy as initially the appearances may be unsightly. Occasionally, the cyst may need to be drained because it has grown too rapidly. However, caution should be observed with this, since there is often a direct connection with the eye itself, and the cyst usually refills in any case. We find that by 2-4 years of age the sockets of most affected children have developed sufficiently for the orbital cyst to be removed. Before this surgery we perform an MRI of the orbits to assess the cyst size, and any potential connection to the brain. After cyst excision and, if necessary, orbital implant, the patients receive a temporary and subsequently custom made ocular prosthesis (Figure 7).

\section{Long-term management}

After the initial socket expansion over the first 5 years of life, the prosthesis and the socket will require review at least yearly. Microphthalmic eyes may develop angle closure glaucoma, which may cause loss of what vision does exist and can also cause pain. ${ }^{17}$ Children with chorioretinal coloboma and their parents should be aware of the increased risk of retinal detachment and receive instructions for prompt attendance in the case of any alteration in vision. ${ }^{18}$ Glasses are prescribed for refractive error, protection, and sometimes for providing lenses to minimise cosmetic defect (such as plus lenses to increase the size of a microphthalmic eye or prisms to equalise a height discrepancy).

\section{Paediatric and genetic follow-up}

Associated systemic abnormalities may have very major implications for the child and so may need considerable input from general or specialist paediatric services. In the case of bilateral anophthalmia or severe microphthalmia with no light perception, there may be a reversal of sleep pattern. In this situation, melatonin supplements at night may be very helpful to establish a regular nocturnal sleep pattern. Growth assessment is important since there may be associated pituitary abnormalities. Developmental assessment by a paediatrician skilled in assessing children with visual problems will detect any early difficulties, but can also provide welcome reassurance for parents, since there is a variance in developmental progress of visually impaired children compared with their sighted peers (www.earlysupport.org.uk) (see Box 1 and Box 2).

It is important to reach an overall diagnosis if possible, since this will direct future management. The parents are 
usually keen to understand the nature of the condition, and a combined approach from paediatrics, ophthalmology, and genetics will help to achieve this. The parents may wish to receive genetic counselling regarding the risks of another child being affected, although in some cases, they may wish to wait. The high incidence of de novo mutations, mosaicism, and variable penetrance, combined with a large overlap in phenotype even among those with the same genetic mutation, makes genetic counselling very complex, ${ }^{19,20}$ and we

Box 1 The role of the ophthalmologist in management of suspected anophthalmia/microphthalmia

1 Confirmation of the diagnosis of anophthalmia, microphthalmia, coloboma, or orbital cyst. Ultrasonography may be very helpful in this.

2 Visual assessment, including electrodiagnostics if possible.

3 Referral to a paediatrician to assess other congenital abnormalities, growth and development, in particular looking for signs of the common systemic associations for example cleft lip/palate, heart defects, kidney and pituitary anomalies, developmental delay.

4 Minimise cosmetic and social impact of anophthalmia or microphthalmia by commencing socket expansion or referring to a specialist unit for socket expansion.

5 Once the diagnosis is confirmed, and at the parents' wishes, referral to a specialist for genetics counselling. would always advise the ophthalmologist involved in the care of these children to involve an ophthalmic or medical geneticist.

\section{Vision and family support}

It is very important that any visually impaired child receives early help from vision support services. The

Box 2 Three major questions most parents want to know

1 What can be done to help my child see?

To a large extent this will depend on whether the condition is unilateral or bilateral. Electrodiagnostic testing will help to determine visual potential. This is followed by early refraction. Where there is potential for vision, clear socket shapes can be used to expand the socket.

2 What can be done cosmetically? The key to this is early socket expansion, with either sequential socket shapes or a hydrophilic expander. Ocular prostheses and if necessary, orbital implants can give excellent results. Further lid surgery may also be needed. Orbital cysts are usually excised when the socket is fully developed, often around 2-4 years of age.

3 Why did it happen and will it happen again in my family? This can be addressed best by genetic testing and counselling, and enrolment in a research study for testing new genes if desired.

Table 1 Selected genes and syndromes associated with eye malformations

\begin{tabular}{|c|c|c|c|c|c|}
\hline Name of Gene & Name of syndrome & Ocular manifestations & Systemic manifestations & Inheritance & Refs \\
\hline SOX2 3q26.3-q27 & $\begin{array}{l}\text { SOX2 anophthalmia } \\
\text { syndrome, some cases of } \\
\text { AEG (anophthalmia- } \\
\text { oesophageal-genital) } \\
\text { syndrome }\end{array}$ & $\begin{array}{l}\text { Anophthalmia, } \\
\text { microphthalmia, cataract, } \\
\text { retinal dystrophy }\end{array}$ & $\begin{array}{l}\text { Hypothalamic - } \\
\text { pituitary abnormalities, } \\
\text { growth failure, genital } \\
\text { tract malformation, } \\
\text { developmental delay, } \\
\text { seizures, oesophageal } \\
\text { atresia }\end{array}$ & $\begin{array}{l}\text { Autosomal } \\
\text { dominant - } \\
\text { usually de novo } \\
\text { mutation }\end{array}$ & $\begin{array}{l}22-24, \\
26,31\end{array}$ \\
\hline $\begin{array}{l}\text { OTX2 } \\
14 q 21-14 q 22\end{array}$ & & $\begin{array}{l}\text { Anophthalmia, } \\
\text { microphthalmia, coloboma, } \\
\text { microcornea, cataract, } \\
\text { retinal dystrophy, optic } \\
\text { nerve hypoplasia }\end{array}$ & $\begin{array}{l}\text { Agenesis of the corpus } \\
\text { callosum, developmental } \\
\text { delay }\end{array}$ & $\begin{array}{l}\text { Autosomal } \\
\text { dominant }\end{array}$ & 20 \\
\hline $\begin{array}{l}\text { PAX2 } \\
\text { 10q24.3-25q.1 }\end{array}$ & $\begin{array}{l}\text { Renal-coloboma } \\
\text { syndrome or } \\
\text { Papillorenal syndrome }\end{array}$ & Coloboma, microphthalmia & Renal hypoplasia & $\begin{array}{l}\text { Autosomal } \\
\text { dominant }\end{array}$ & 32 \\
\hline PAX6 11p13 & & $\begin{array}{l}\text { Aniridia, Peters' anomaly, } \\
\text { foveal hypoplasia, } \\
\text { keratopathy }\end{array}$ & $\begin{array}{l}\text { Abnormalities of } \\
\text { pituitary, pancreatic, and } \\
\text { brain development }\end{array}$ & $\begin{array}{l}\text { Autosomal } \\
\text { dominant, } \\
\text { compound } \\
\text { heterozygotes } \\
\text { have } \\
\text { anophthalmia }\end{array}$ & $\begin{array}{l}25,26, \\
33\end{array}$ \\
\hline CHD7 8q12.1 & CHARGE syndrome & Microphthalmia, coloboma & $\begin{array}{l}\text { Heart defects, choanal } \\
\text { atresia, retarded growth } \\
\text { and development, } \\
\text { genital hypoplasia, ear } \\
\text { anomalies, and deafness }\end{array}$ & $\begin{array}{l}\text { Autosomal } \\
\text { dominant }\end{array}$ & 27,28 \\
\hline
\end{tabular}


Table 1 (Continued)

\begin{tabular}{|c|c|c|c|c|c|}
\hline Name of Gene & Name of syndrome & Ocular manifestations & Systemic manifestations & Inheritance & Refs \\
\hline РТCH 9q22.3 & $\begin{array}{l}\text { Basal cell naevus } \\
\text { syndrome/Gorlin's } \\
\text { syndrome }\end{array}$ & $\begin{array}{l}\text { Microphthalmia, coloboma, } \\
\text { cyst }\end{array}$ & $\begin{array}{l}\text { Palmer pits, } \\
\text { medulloblastoma basal } \\
\text { cell carcinoma }\end{array}$ & $\begin{array}{l}\text { Autosomal } \\
\text { dominant }\end{array}$ & 29 \\
\hline SHH 7q36 & $\begin{array}{l}\text { Holoprosencephaly-3 } \\
\text { (HPE3) }\end{array}$ & $\begin{array}{l}\text { Cyclopia, coloboma, } \\
\text { hypotelorism }\end{array}$ & $\begin{array}{l}\text { Preaxial polydactyly, } \\
\text { cleft lip and palate }\end{array}$ & $\begin{array}{l}\text { Autosomal } \\
\text { dominant }\end{array}$ & 30,34 \\
\hline CHX10 14q24.3 & & $\begin{array}{l}\text { Anophthalmia, } \\
\text { microphthalmia, coloboma, } \\
\text { cataract, iris abnormalities }\end{array}$ & & $\begin{array}{l}\text { Autosomal } \\
\text { recessive }\end{array}$ & 19,21 \\
\hline FOXC1 6p25 & $\begin{array}{l}\text { Axenfeld-Rieger } \\
\text { syndrome }\end{array}$ & $\begin{array}{l}\text { Iris hypoplasia, } \\
\text { iridogoniodysgenesis, } \\
\text { glaucoma }\end{array}$ & $\begin{array}{l}\text { Dental abnormalities, } \\
\text { midface abnormalities }\end{array}$ & $\begin{array}{l}\text { Autosomal } \\
\text { dominant }\end{array}$ & 35 \\
\hline HCCS Xp22 & $\begin{array}{l}\text { Microphthalmia with } \\
\text { linear skin defects }\end{array}$ & $\begin{array}{l}\text { Microphthalmia, } \\
\text { sclerocornea }\end{array}$ & $\begin{array}{l}\text { Linear skin defects, } \\
\text { agenesis of corpus } \\
\text { callosum }\end{array}$ & $\begin{array}{l}\text { X-linked } \\
\text { dominant }\end{array}$ & 36 \\
\hline BRIP1 17q22 & Fanconi anaemia & Microphthalmia & $\begin{array}{l}\text { Bone marrow failure, } \\
\text { breast cancer, growth } \\
\text { retardation, café-au-lait } \\
\text { spots, hearing loss, } \\
\text { thumb and kidney } \\
\text { abnormalities }\end{array}$ & $\begin{array}{l}\text { Autosomal } \\
\text { dominant }\end{array}$ & 37 \\
\hline$D P D 1 \mathrm{p} 22$ & & $\begin{array}{l}\text { Microphthalmia, coloboma, } \\
\text { nystagmus }\end{array}$ & $\begin{array}{l}\text { Epilepsy, mental } \\
\text { retardation, motor } \\
\text { retardation }\end{array}$ & $\begin{array}{l}\text { Autosomal } \\
\text { recessive }\end{array}$ & 38 \\
\hline SIX3 2p21 & Holoprosencephaly 2 & $\begin{array}{l}\text { Cyclopia, Microphthalmia, } \\
\text { coloboma }\end{array}$ & $\begin{array}{l}\text { hypotelorism, } \\
\text { microcephaly, } \\
\text { craniofacial anormalities }\end{array}$ & $\begin{array}{l}\text { Autosomal } \\
\text { dominant }\end{array}$ & 39 \\
\hline SIX6 14q23 & & $\begin{array}{l}\text { Microphthalmia, cataract, } \\
\text { nystagmus }\end{array}$ & Pituitary abnormalities & $\begin{array}{l}\text { Autosomal } \\
\text { dominant }\end{array}$ & 40,41 \\
\hline PITX2 4p25 & Rieger syndrome & $\begin{array}{l}\text { Iris hypoplasia, } \\
\text { iridogoniodysgenesis, } \\
\text { glaucoma }\end{array}$ & $\begin{array}{l}\text { Maxillary hypoplasia, } \\
\text { dental abnormalities, } \\
\text { excess periumbilical skin }\end{array}$ & $\begin{array}{l}\text { Autosomal } \\
\text { dominant }\end{array}$ & 42 \\
\hline POMT1 9q34.1 & $\begin{array}{l}\text { Walker-Warburg } \\
\text { syndrome }\end{array}$ & $\begin{array}{l}\text { Microphthalmia, cataract, } \\
\text { anterior chamber } \\
\text { abnormalities, retinal } \\
\text { dysplasia and detachment, } \\
\text { persistent hyperplastic } \\
\text { primary vitreous, coloboma, } \\
\text { optic nerve hypoplasia }\end{array}$ & $\begin{array}{l}\text { Developmental delay, } \\
\text { muscular dystrophy, } \\
\text { hydrocephalus, agyria, } \\
\text { epilepsy }\end{array}$ & $\begin{array}{l}\text { Autosomal } \\
\text { recessive }\end{array}$ & 43 \\
\hline BCOR Xq27-q28 & $\begin{array}{l}\text { Oculofaciocardiodental } \\
\text { syndrome }\end{array}$ & $\begin{array}{l}\text { Microphthalmia, congenital } \\
\text { cataract }\end{array}$ & $\begin{array}{l}\text { Mental retardation, heart } \\
\text { defects, dental and facial } \\
\text { abnormalities }\end{array}$ & $X$-linked recessive & 44 \\
\hline$R X 18 \mathrm{q} 21.3$ & & $\begin{array}{l}\text { Anophthalmia, } \\
\text { microphthalmia, } \\
\text { sclerocornea }\end{array}$ & & $\begin{array}{l}\text { Autosomal } \\
\text { recessive }\end{array}$ & 45 \\
\hline FRAS1 4q21 & Fraser Syndrome & $\begin{array}{l}\text { Microphthalmia, } \\
\text { cryptophthalmos }\end{array}$ & $\begin{array}{l}\text { Genital and kidney } \\
\text { abnormalities, finger } \\
\text { webbing }\end{array}$ & $\begin{array}{l}\text { Autosomal } \\
\text { recessive }\end{array}$ & 46 \\
\hline FREM2 13q13.3 & Fraser Syndrome & $\begin{array}{l}\text { Microphthalmia, } \\
\text { cryptophthalmos }\end{array}$ & $\begin{array}{l}\text { Genital and kidney } \\
\text { abnormalities, finger } \\
\text { webbing }\end{array}$ & $\begin{array}{l}\text { Autosomal } \\
\text { recessive }\end{array}$ & 47 \\
\hline $\begin{array}{l}\text { HESX1 } \\
\text { 3p21.2-p21.1 }\end{array}$ & Septo-optic dysplasia & Optic nerve hypoplasia & $\begin{array}{l}\text { Agenesis of the corpus } \\
\text { callosum, } \\
\text { panhypopituitarism, and } \\
\text { absent septum } \\
\text { pellucidum }\end{array}$ & $\begin{array}{l}\text { Autosomal } \\
\text { dominant }\end{array}$ & 48 \\
\hline MAF 16q22-q23 & & $\begin{array}{l}\text { Cataract, anterior segment } \\
\text { dysgenesis, coloboma }\end{array}$ & Nephritic syndrome & $\begin{array}{l}\text { Autosomal } \\
\text { dominant }\end{array}$ & 49 \\
\hline
\end{tabular}


Table 1 (Continued)

\begin{tabular}{|c|c|c|c|c|c|}
\hline Name of Gene & Name of syndrome & Ocular manifestations & Systemic manifestations & Inheritance & Refs \\
\hline $\begin{array}{l}\text { RAB3GAP } \\
2 \mathrm{q} 21.3\end{array}$ & $\begin{array}{l}\text { Warburg Micro } \\
\text { Syndrome }\end{array}$ & $\begin{array}{l}\text { Microphthalmia, } \\
\text { microcornea, optic atrophy, } \\
\text { cataract }\end{array}$ & $\begin{array}{l}\text { Microcephaly, mental } \\
\text { retardation, hypoplasia } \\
\text { of corpus callosum, } \\
\text { hypothalamic } \\
\text { hypogenitalism }\end{array}$ & $\begin{array}{l}\text { Autosomal } \\
\text { recessive }\end{array}$ & 50 \\
\hline
\end{tabular}

For a more complete list of conditions associated with coloboma, the reader is referred to the reviews by Gregory-Evans et al. and Chang et al. 5

child may qualify for a Certificate of Visual Impairment, which may help to expedite some of the services and financial support available. There are publications, such as 'Show me what my child can see' (available from the Wolfson Centre, Mecklenburg Sq, London WC1N 2AP) which can help parents to interact with their babies if visually impaired. Early intervention undoubtedly makes a huge difference to the overall development of the child and the emotional well-being of the family.

In addition to the more widely known organisations for the visually impaired, there are two British charities, the Eyeless Trust (www.eyeless.org.uk) and MACS (Microphthalmic and Anophthalmic Children's Society, www.macs.org.uk) who can offer specialist advice and family support to these children and their families. Other charities that can be very helpful to these children include VICTA (Visually Impaired Children Taking Action, www.victa.org.uk), VISION and LOOK (The National Federation of Families with Visually Impaired Children, www.look-uk.org).

\section{Aetiology and genetics}

The development of the eye is highly complex. It is determined by sequential and coordinated expression of eye development genes within the developing tissues. Although some individuals with anophthalmia or microphthalmia have relatives with other eye malformations, the frequent lack of clear Mendelian inheritance in these conditions has made identifying the genes for eye development very challenging. However, using a variety of techniques, some genes involved in anophthalmia or microphthalmia have now been identified (see Table 1). These include genes principally involved in ocular development, such as CHX10, many of which are involved in the development of substructures within the eye $\mathrm{e}^{19,21}$ and genes that are involved in eye and brain development including SOX2, OTX2, and $P A X 6{ }^{20,22-26}$ Several syndromic genes are involved in developing other organs in addition to the eye, including CHD7, the gene for CHARGE syndrome ${ }^{27,28}$ and PTCH, the gene for Gorlin syndrome..$^{29}$ There is a complex interplay between the different eye development gene pathways, which allows their expression to be finely regulated ${ }^{5,27,30}$ and begins to explain why there is such an overlap of the phenotypes associated with mutations of each gene.

\section{Acknowledgements}

Nicola Ragge is a Senior Surgical Scientist supported through an Academy of Medical Sciences and Health Foundation Fellowship. www.acmedsci.ac.uk; www.health.org.uk. We are extremely grateful to many who support the specialist anophthalmia and microphthalmia services, in particular our consultant colleagues, Mr Yassir Abou-Rayyah, Dr Alison Salt; the prosthetists: Nigel Sapp, David Carpenter and Peter Coggin; Marie Restori for ultrasound, Medical Illustration, Chris Timms and all the orthoptists, the paediatric nurses, Christine Ennals, family support services, Dr Graham Holder Electrodiagnostics Dept., optometry services, and Celestria Bell for family liaison. We acknowledge with deepest gratitude the generous support from the Eyeless Trust, VICTA and the Polak Trust. Above all, we wish to dedicate this article to the individuals with anophthalmia and microphthalmia and their families.

\section{References}

1 Shaw GM, Carmichael SL, Yang W, Harris JA, Finnell RH, Lammer EJ. Epidemiologic characteristics of anophthalmia and bilateral microphthalmia among 2.5 million births in California, 1989-1997. Am J Med Genet A 2005; 137(1): 36-40.

2 Kallen B, Tornqvist K. The epidemiology of anophthalmia and microphthalmia in Sweden. Eur J Epidemiol 2005; 20(4): 345-350.

3 Morrison D, Fitzpatrick D, Hanson I, Williamson K, van Heyningen V, Fleck B et al. National study of microphthalmia, anophthalmia and coloboma (MAC) in Scotland; Investigation of genetic aetiology. J Med Genet 2002; 39(1): 16-22.

4 Tucker S, Jones B, Collin JRO. Systemic anomalies in 77 patients with congenital anophthalmos or microphthalmos. Eye 1996; 10: 310-314.

5 Gregory-Evans CY, Williams MJ, Halford S, Gregory-Evans $\mathrm{K}$. Ocular coloboma: a reassessment in the age of molecular neuroscience. J Med Genet 2004; 41: 881-891. 
6 Chang L, Blain D, Bertuzzi S, Brooks BP. Uveal coloboma and basic science update. Curr Opin Ophthalmol 2006; 17: 447-470.

7 Vermeif-Keers C. Primary congenital aphakia and the rubella syndrome. Teratology 1975; 11(3): 257-265.

8 Palano GM, Di Pietro M, Scuderi A, Pratico G. Microphthalmia due to congenital varicella infection: a case report. Minerva Pediatr 2005; 57(6): 433-439.

9 Kodjikian L, Wallon M, Fleury J, Denis P, Binquet C, Peyron $\mathrm{F}$ et al. Ocular manifestations in congenital toxoplasmosis. Graefes Arch Clin Exp Ophthalmol 2006; 244(1): 14-21.

10 Hutto C, Arvin A, Jacobs R, Steele R, Stagno S, Lyrene R et al. Intrauterine herpes simplex virus infections. J Pediatr 1987; 110(1): 97-101.

11 Nigro G, Sali E, Anceschi MM, Mazzocco M, Maranghi L, Clerico A et al. Foscarnet therapy for congenital cytomegalovirus liver fibrosis following prenatal ascites. J Matern Fetal Neonatal Med 2004; 15(5): 325-329.

12 Farkas LG, Posnick JC, Hreczko TM. Growth patterns in the orbital region: a morphometric study. Cleft Palate-Craniofac J 1992; 29: 315-318.

13 Wiese KG, Vogel M, Guthoff R, Gundlach KK. Treatment of congenital anophthalmos with self-inflating polymer expanders: a new method. I Craniomaxillofac Surg 1999; 27(2): 72-76.

14 Gundlach KK, Guthoff RF, Hingst VH, Schittkowski MP, Bier UC. Expansion of the socket and orbit for congenital clinical anophthalmia. Plast Reconstr Surg 2005; 116(5): 1214-1222.

15 McLean CJ, Ragge NK, Jones RB, Collin JR. The management of cysts associated with congenital microphthalmos and anophthalmos. Br J Ophthalmol 2003; 87(7): 860-863.

16 Shawkat FS, Harris CM, Taylor DS, Thompson DA, Russell-Eggitt I, Kriss A. The optokinetic response differences between congenital profound and nonprofound unilateral visual deprivation. Ophthalmology 1995; 102(11): $1615-1622$

17 Demirci H, Singh AD, Shields JA, Shields CL, Eagle RC. Bilateral microphthalmos and orbital cyst. Eye 2003; 17: 273-276.

18 Daufenbach DR, Ruttum MS, Pulido JS, Keech RV. Chorioretinal colobomas in a pediatric population. Ophthalmology 1998; 105(8): 1455-1458.

19 Bar-Yosef U, Abuelaish I, Harel T, Hendler N, Ofir R, Birk OS. CHX10 mutations cause non-syndromic microphthalmia/anophthalmia in Arab and Jewish kindreds. Hum Genet 2004; 115(4): 302-309.

20 Ragge NK, Brown AG, Poloschek CM, Lorenz B, Henderson RA, Clarke MP et al. Heterozygous mutations of OTX2 cause severe ocular malformations. Am J Hum Genet 2005; 77(2): 334

21 Ferda Percin E, Ploder LA, Yu JJ, Arici K, Horsford DJ, Rutherford A et al. Human microphthalmia associated with mutations in the retinal homeobox gene CHX10. Nat Genet 2000; 25(4): 397-401.

22 Fantes JA, Ragge NK, Lynch SA, McGill N, Collin JR, Howard-Peebles PN et al. Mutations in SOX2 cause anophthalmia. Nat Genet 2003; 33: 461-463.

23 Ragge NK, Lorenz B, Schneider A, Bushby K, de Sanctis L, de Sanctis U et al. SOX2 anophthalmia syndrome. Am J Med Genet A 2005; 135(1): 1-7.

24 Bakrania P, Robinson DO, Bunyan DJ, Salt A, Martin A, Crolla JA et al. SOX2 anophthalmia syndrome: twelve new cases demonstrating broader phenotype and high frequency of large gene deletions. Br J Ophthalmol 2007 [E-pub ahead of print].

25 Glaser T, Jepeal L, Edwards JG, Young SR, Favor J, Maas RL. $P A X 6$ gene dosage effect in a family with congenital cataracts, aniridia, anophthalmia and central nervous system defects. Nat Genet 1994; 7(4): 463-471.

26 Hever AM, Williamson KA, van Heyningen V. Developmental malformations of the eye: the role of PAX6, SOX2 and OTX2. Clin Genet 2006; 69(6): 459-470.

27 Vissers LE, van Ravenswaaij CM, Admiraal R, Hurst JA de Vries BBA, Janssen IM et al. Mutations in a new member of the chromodomain gene family cause CHARGE syndrome. Nat Genet 2004; 36: 955-957.

28 Lalani SR, Safiullah AM, Fernbach SD, Harutyunyan KG, Thaller C, Peterson LE et al. Spectrum of CHD7 mutations in 110 individuals with CHARGE syndrome and genotype-phenotype correlation. Am J Hum Genet 2006; 78: 303-314.

29 Ragge NK, Salt A, Collin JRO, Michalski A, Farndon PA. Gorlin syndrome: the PTCH gene links ocular developmental defects and tumour formation. $\mathrm{Br} J$ Opthamol 2005; 89: 988-991.

30 Nanni L, Ming JE, Bocian M, Steinhaus K, Bianchi DW, de Die-Smulders $\mathrm{C}$ et al. The mutational spectrum of the Sonic hedgehog gene in holoprosencephaly: $\mathrm{SHH}$ mutations cause a significant proportion of autosomal dominant holoprosencephaly. Hum Mol Genet 1999; 8: 2479-2488.

31 Williamson KA, Hever AM, Rainger J, Rogers RC, Magee A, Fiedler $\mathrm{Z}$ et al. Mutations in SOX2 cause anophthalmiaesophageal-genital (AEG) syndrome. Hum Mol Genet 2006; 15(9): 1413-1422.

32 Schimmenti LA, Cunliffe HE, Mc Noe LA, Ward TA, French MC, Shim HH et al. Further delineation of renal-coloboma syndrome in patients with extreme variability of phenotype and identical PAX2 mutations. Am J Hum Genet 1997; 60: 869-878.

33 Azuma N, Yamaguchi Y, Handa H, Tadokoro K, Asaka A, Kawase $\mathrm{E}$ et al. Mutations of the PAX6 gene detected in patients with a variety of optic nerve malformations. Am J Hum Genet 2003; 72: 1565-1570.

34 Belloni E, Muenke M, Roessler E, Traverso G, Siegel-Bartelt J, Frumkin A et al. Identification of Sonic Hedgehog as a candidate gene responsible for holoprosencephaly. Nat Genet 1996; 14: 353-356.

35 Nishimura DY, Swiderski RE, Alward WLM, Searby CC, Patil SR, Bennet SR et al. The forkhead transcription factor gene $F K H L 7$ is responsible for glaucoma phenotypes which map to 6p25. Nat Genet 1998; 19: 140-147.

36 Wimplinger I, Morleo M, Rosenberger G, Iaconis D, Orth U, Meinecke $\mathrm{P}$ et al. Mutations of the mitochondrial holocytochrome c-type synthase in X-linked dominant microphthalmia with linear skin defects syndrome. Am J Hum Genet 2006; 79: 878-889.

37 Levran O, Attwooll C, Henry RT, Milton KL, Neveling K, Rio $P$ et al. The BRCA1-interacting helicase BRIP1 is deficient in Fanconi anemia. Nat Genet 2005; 37: 931-933. Note: Addendum: Nat Genet. 2005. 37: 1296.

38 van Gennip AH, Abeling NG, Stroomer AEM, van Lenthe $H$, Bakker HD. Clinical and biochemical findings in six patients with pyrimidine degradation defects. J Inherit Metab Dis 1994; 17: 130-132.

39 Wallis DE, Roessler E, Hehr U, Nanni L, Wiltshire T, Richieri-Costa A et al. Mutations in the human SIX3 gene cause holoprosencaphaly. Nat Genet 1999; 22: 196-198. 
40 Gallardo ME, Rodriguez de Cordoba S, Schneider AS, Dwyer MA, Ayuso C, Bovolenta P. Analysis of the developmental SIX6 homeobox gene in patients with anophthalmia/microphthalmia. (Letter) Am J Med Genet 2004; 129A: 92-94.

41 Aijaz S, Clark BJ, Williamson K, van Heyningen V, Morrison $\mathrm{D}$, Fitzpatrick D et al. Absence of SIX6 mutations in microphthalmia, anophthalmia and coloboma. Invest Ophthalmol Vis Sci 2004; 45(11): 3871-3876.

42 Semina EV, Reiter R, Leysens NJ, Alward WLM, Small KW, Datson NA et al. Cloning and characterization of a novel bicoid-related homeobox transcription factor gene, RIEG, involved in Rieger syndrome. Nat Genet 1996; 14: 392-399.

43 Beltran-Valero de Bernabe D, Currier S, Steinbrecher A, Celli J, van Beusekom E, van der Zwaag B et al. Mutations in the $O$-mannosyltransferase gene POMT1 give rise to the severe neuronal migration disorder WalkerWarburg syndrome. Am J Hum Genet 2002; 71: 1033-1043.

44 Ng D, Thakker N, Corcoran CM, Donnai D, Perveen R, Schneider A et al. Oculofaciocardiodental and Lenz microphthalmia syndromes result from distinct classes of mutation in BCOR. Nat Genet 2004; 36: 411-416.

45 Voronina VA, Kozhemyakina EA, O'Kernick CM, Kahn ND, Wenger SL, Linberg JV et al. Mutations in the human $R A X$ homeobox gene in a patient with anophthalmia and sclerocornea. Hum Mol Genet 2004; 13: 315-322.

46 McGregor L, Makela V, Darling SM, Vrontou S, Chalepakis $\mathrm{G}$, Roberts $\mathrm{C}$ et al. Fraser syndrome and mouse blebbed phenotype caused by mutations in FRAS1/Fras1 encoding a putative extracellular matrix protein. Nat Genet 2003; 34: 203-208.

47 Jadeja S, Smyth I, Pitera JE, Taylor MS, van Haelst M, Bentley $\mathrm{E}$ et al. Identification of a new gene mutated in Fraser syndrome and mouse myelencephalic blebs. Nat Genet 2005; 37: 520-525.

48 Thomas PQ, Dattani MT, Brickman JM, McNay D, Warne G, Zacharin $\mathrm{M}$ et al. Heterozygous HESX1 mutations associated with isolated congenital pituitary hypoplasia and septo-optic dysplasia. Hum Mol Genet 2001; 10: 39-45.

49 Jamieson RV, Perveen R, Kerr B, Carette M, Yardley J, Heon E et al. Domain disruption and mutation of the bZIP transcription factor, $M A F$, associated with cataract, ocular anterior segment dysgenesis and coloboma. Hum Mol Genet 2002; 11: 33-42.

50 Aligianis IA, Johnson CA, Gissen P, Chen D, Hampshire D, Hoffman $\mathrm{K}$ et al. Mutations of the catalytic subunit of RAB3GAP cause Warburg Micro syndrome. Nat Genet 2005; 37: 221-223. 